\title{
The NLRA and the Duty of Loyalty: Protecting Public Disparagement
}

\author{
Ron Lepinskas†
}

A duty of employee loyalty seems ill-suited to modern-day labor relations, where employees often drive employers toward economic ruin in order to gain bargaining concessions. Indeed, in enacting the National Labor Relations Act ("NLRA"), ${ }^{1}$ Congress expressly protected many disloyal employee actions, including work stoppages ${ }^{2}$ and picketing. ${ }^{3}$ The NLRA, however, fails to address directly whether employees who publicly disparage their employers' business activities deserve protection from reprisals. Drawing on the Supreme Court's opinion in NLRB v Local Union No. 1229 ("Jefferson Standard"), the National Labor Relations Board ("NLRB" or "Board") and federal circuit courts have attempted to fill this gap by permitting an employer to fire employees who commit acts of "indefensible" disloyalty during a labor dispute. However, no satisfactory standard has emerged for determining the point at which disparagement becomes "indefensible."

The lack of a satisfactory standard threatens the rights of employees engaged in labor disputes. Disloyalty is a pliable and subjective concept that could chill much employee activity currently protected by the NLRA. ${ }^{5}$ Moreover, the disloyalty doctrine has ap-

† A.B. 1989, Dartmouth College; J.D. 1993, The University of Chicago.

129 USC $\$ \S 151-69$ (1988).

229 USC \& 163 (1988). Section 163 states: "Nothing in this subchapter, except as specifically provided for herein, shall be construed so as either to interfere with or impede... in any way the right to strike ...."

s 29 USC \& 158(b)(7) (1988). Section 8(b)(7) prohibits picketing for certain objectives. Implicitly recognized, though, is the right to picket for other objectives. See generally Julius G. Getman and John D. Blackburn, Labor Relations: Law, Practice and Policy 513-14 (Foundation Press, 2d ed 1983) (discussing the historical use of picketing as an organizational tool and the creation of $\S 8(b)(7)$ as a compromise between interests of labor and management).

4 346 US 464 (1953).

s See 346 US at 479-80 (Frankfurter dissenting) ("Many of the legally recognized tactics and weapons of labor would readily be condemned for 'disloyalty' were they employed between man and man in friendly personal relations."). See also Case Comment, Loyalty as Proper Grounds for Discharge, 1954 U III Law F 137, 140 ("Disloyalty is a loose concept and conceivably could be invoked in almost any situation where employees have a dispute with their employer."). 
pealed to courts deciding other employment actions, such as those under the Equal Employment Opportunity Act ${ }^{6}$ and the common law of employment contracts. ${ }^{7}$ In all of these employment settings, "disloyalty" often marks the line between unemployment and reinstatement with back pay.

This Comment examines the judicial application of the disloyalty doctrine and then proposes a new standard for determining what kinds of public disparagement the NLRA protects. Section I explores the statutory framework applicable to public disparagement issues, as well as the legislative history behind that framework. Section II traces the judicial evolution of the disloyalty doctrine. Finally, Section III proposes importing the distinction between mandatory and permissive subjects of bargaining to define the border between protected activity and unprotected disloyalty.

\section{The National Labor Relations Act}

The Wagner Act ${ }^{8}$ and the Taft-Hartley Act, ${ }^{9}$ comprising most of the present NLRA, provides the statutory framework behind the disloyalty doctrine. ${ }^{10}$ Against a historic backdrop of meager and constitutionally uncertain employment rights, ${ }^{11}$ the Wagner Act and its forerunners accorded employees the right, among

- See, for example, Hochstad̀t $v$ Worcester Foundation, 545 F2d 222, 233-34 (1st Cir 1976) (employee's disloyalty in complaints over salary and ratings and interference with laboratory research" provided nondiscriminatory basis for discharge under Title VII of Civil Rights Act).

T See Heller $v$ Champion Int'l Corp., 891 F2d 432, 436 (2d Cir 1989) (employee's secret taping of discussions with employer in anticipation of action for breach of implied employment contract is not disloyal).

s Pub L No 74-198, 49 Stat 449 (1935), codified as amended at 29 USC $\$ \$ 151-69$ (1988).

- Pub L No 80-101, 61 Stat 136 (1947), codified as amended at 29 USC $\$ \$ 151-69$ (1988).

10 The Landrum-Griffin Act, Pub L No 86-257, 73 Stat 519 (1959), codified at 29 USC \$ 151-69 (1988), also provides a large portion of the present NLRA. However, the Landrum-Griffin Act largely concerned subjecting internal union affairs to federal regulation. It also tightened the secondary boycott provisions of the NLRA, restricted organizational and recognitional picketing, and conferred upon states jurisdiction over cases declined by the NLRB. See Getman and Blackburn, Labor Relations at 36 (cited in note 3).

11 On the legal landscape prior to protective legislation, Lewis L. Lorwin and Arthur Wubnig wrote:

Employers were ... legally free to impose upon their employees any forms of labor organization which it suited their convenience to impose. Employers also had the right to hire and fire for any and all reasons. Most significant with reference to labor organizations was the right of employers to hire and fire on the basis of the wage earner's labor union affiliations.

Lewis L. Lorwin and Arthur Wubnig, Labor Relations Boards 448 (Brookings, 1935). The Supreme Court has also stated: 
others, to organize and bargain collectively. In reaction to resulting disparities, the Taft-Hartley Act provided employers with rights that its conservative sponsors hoped would restore a balance of bargaining strength in industrial relations. Between these two sets of rights lies the disloyalty doctrine.

\section{A. Statutory Framework}

The NLRA protects employees from reprisals for most activities arising out of labor disputes. Section 7 states, in part, that "[e]mployees shall have the right ... to engage in ... concerted activities for the purpose of collective bargaining or other mutual aid or protection ...."12 Section 8(a)(1), the enforcement provision behind this right, forbids an employer "to interfere with, restrain, or coerce employees in the exercise of the rights guaranteed in [§ 7]."1s If an employer violates § 8(a)(1), the NLRB will find the employer guilty of an unfair labor practice and will order remedial action as directed by $\S 10(\mathrm{c}) .^{14}$

These provisions create a broad prohibition on employer interference with union activity, but the activity must meet two conditions to receive protection: it must be "concerted" and it must be within the judicially created class of "protected" activities.15 Courts have construed the "concerted" requirement broadly. Any action by two or more employees acting together is automatically

[Labor unions] were organized out of the necessities of the situation. A single employee was helpless in dealing with an employer. He was dependent ordinarily on his daily wage for the maintenance of himself and family. If the employer refused to pay him the wages that he thought fair, he was nevertheless unable to leave the employ and to resist arbitrary and unfair treatment.

American Steel Foundries v Tri-City Central Trades Council, 257 US 184, 209 (1921). Rights granted by the National Industrial Recovery Act, 48 Stat 195 (1933) ("NRA"), were constitutionally uncertain. See Lorwin and Wubnig, Labor Relations Boards at 446-47 (discussing constitutional concerns).

1229 USC § 157 (1988). Section 7 states in full:

Employees shall have the right to self-organization, to form, join, or assist labor organizations, to bargain collectively through representatives of their own choosing, and to engage in other concerted activities for the purpose of collective bargaining or other mutual aid or protection, and shall also have the right to refrain from any or all of such activities except to the extent that such right may be affected by an agreement requiring membership in a labor organization as a condition of employment as authorized in section [8(a)(3)].

1329 USC \& 158(a)(1) (1988).

1429 USC \& 160(c) (1988).

1s Protected is a term of art not drawn from $\S 7$. The courts invented this requirement so as to avoid holding all concerted activity lawful. See, for example, NLRB v City Disposal Systems, 465 US 822, 837 (1984) ("The fact that an activity is concerted [] does not necessarily mean that an employee can engage in the activity with impunity."). 
"concerted." 16 Even a single employee's action may satisfy this requirement. For example, if a single employee asserts a right grounded in a collective bargaining agreement, this action is "concerted."17

The second requirement, that the activity fall within a protected class of activities, is also construed broadly. It generally encompasses activity for the "mutual aid or protection" of fellow employees, which the Board and the courts have construed to include most forms of concerted employee activity. ${ }^{18}$ However, the Board and the courts have withheld protection from two kinds of activities: 'those that have an objective that is unlawful or in violation of an NLRA policy, ${ }^{19}$ and those that employ means involving major violence or misconduct. ${ }^{20}$

Section 10(c) also limits the scope of protected activity. That section, in part, removes the protection of the NLRA from an em- ployee who is discharged "for cause."21 Activities that would lead to a dismissal "for cause" are thus defined as being beyond the territory protected by $\S 7$. But while $\S 7$ and $\S 10$ (c) purport to define the limits of NLRA protection, they do not yield a firm border between protected and unprotected activity.

\section{B. Legislative History}

Sections 7 and 10 (c) of the NLRA reflect different eras and legislative objectives. Section 7 manifests the pro-union objective of the New Deal supporters of the Wagner Act, ${ }^{22}$ which consoli-

16 See id at 831.

${ }^{17}$ See id at 831-32. See also, Note, Individual Rights for Organized and Unorganized Employees Under the National Labor Relations Act, 58 Tex L Rev 991 (1980) (exploring policies behind protection of employee acting alone).

${ }^{18}$ See, for example, Eastex, Inc. $v$ NLRB, 437 US 556, 570 (1978) (distribution on employer's property of union newsletter seeking pro-union political agitation protected).

10 See Southern Steamship Co. $v$ NLRB, 316 US 31, 39-48 (1942) (strike that constituted mutiny under criminal code unprotected); Thompson Products, Inc., 72 NLRB 886, 887-89 (1947) (strike to compel employer to violate NLRB certification of a different union unprotected).

${ }^{20}$ See Elk Lumber, 91 NLRB 333, 338-39 (1950) (slowdown unprotected); Audubon Health Care Center, 268 NLRB 135, 136 (1983) (partial work stoppages unprotected); Columbia Portland Cement Co. $v$ NLRB, 915 F2d 253, 258-59 (6th Cir 1990) (employee who attacked non-striking employee with baseball bat lawfully discharged).

2129 USC \& 160(c) (1988). Section 10(c) states in relevant part: "No order of the Board shall require the reinstatement of any individual as an employee who has been suspended or discharged ... for cause."

${ }^{22}$ See Benjamin S. Kirsh, The National Industrial Recovery Act: An Analysis 16 (Central Book, 1933) (detailing how the predecessor to the Wagner Act was companion legislation to other New Deal measures, such as the Agricultural Adjustment Act). 
dated previous statutory efforts to improve the lot of employees. ${ }^{23}$ In contrast, $\S 10$ (c) reflects the purposes of a Republican Congress twelve years later, amending $\S 10(\mathrm{c})$ as part of its response, in the Taft-Hartley Act, to the rising strength of trade unions. ${ }^{24}$

Supporters of the Wagner Act wanted to promote employees' rights to organize and to bargain collectively, but they otherwise sought no change in existing labor law. ${ }^{25}$ They were not concerned with conduct at the margins, so they did not define $\S 7$ rights with enough clarity to determine whether it protected public disparagement. ${ }^{28}$ As with the NRA, ${ }^{27}$ so anxious was Congress to combat the effects of the Depression that debate over fundamental elements of the bill supplanted debate over the outer limits of $\S 7$ protection.

A conception of bilateral obligations on employers and unions underlay the Wagner Act. Prior to the labor acts of the early $1930 \mathrm{~s},{ }^{28}$ Wagner Act supporters maintained employers enjoyed natural advantages of organization over employees as well as some judicial favoritism. ${ }^{20}$ The Wagner Act was designed to create equal bargaining strength by granting employees rights that employers already enjoyed. ${ }^{30}$ For instance, under $\S 7$, employees could select

${ }^{23}$ Congress passed the Wagner Act in the wake of the failure of the National Industrial Recovery Act. Like the later Wagner Act, the NRA protected unionization and collective bargaining. See Getman and Blackburn, Labor Relations at 29 (cited in note 3).

24 See Gerard D. Reilly, The Legislative History of the Taft-Hartley Act, 29 Geo Wash $L$ Rev 285, 285 (1960) ("With the continued growth in the economic and political power of organized labor ...., the primary objective of Congress ... was to restore sufficient equilibrium to ... industrial relations to enable our traditional system of private enterprise to continue.").

2s Senator Walsh, a key supporter of the Wagner Act, stated:

[The bill] makes absolutely no change whatever in existing law, so far as the relation of employers and employees are concerned, except in those limited respects that relate to collective bargaining and the right of employees to organize without interference by employers.

79 Cong Rec 7658, reprinted in 2 Legislative History of the National Labor Relations Act, 19352369 (NLRB, 1949).

${ }^{26}$ For a fuller discussion of the debate over \& 7, see Lorwin and Wubnig, Labor Relations Boards at 29-44 (cited in note 11). For a history of $\S 7$, see Robert A. Gorman and Matthew W. Finkin, The Individual and the Requirement of "Concert" Under the National Labor Relations Act, $130 \mathrm{U} \mathrm{Pa} \mathrm{L}$ Rev 286, 331-46 (1981).

${ }^{27}$ For a fuller discussion of the debate over $\S 7$ (a) of the NRA, the antecedent to $\S 7$ of the Wagner Act, see William H. Spencer, Collective Bargaining Under Section 7(a) of the NIRA 4-6 (Chicago, 1935).

28 See for instance, the Norris-LaGuardia Anti-Injunction Act of 1932, 47 Stat 70 (1932), codified at 29 USC $\S \S 101-15$ (1988).

29 See Duplex Printing Press Co. v Deering, 254 US 443, 484-85 (1921) (Brandeis dissenting) (discussing judicial bias favoring employers over employees).

30 See S Rep No 573 on S 1958, 74th Cong, 1st Sess 3 (1935), reprinted in 2 Legislative History of the NLRA at 2302 (cited in note 25) ("[E]quality of bargaining power [] is a prerequisite to equality of opportunity and freedom of contract. The relative weakness of 
their own bargaining representatives free of employer interference; employers could hardly deny that they already enjoyed that right. ${ }^{31}$

Supporters of the Taft-Hartley Act shared this conception of imposing bilateral obligations. However, they correctly believed that the Wagner Act had placed obligations on employers that did not bind employees. ${ }^{32}$ The Taft-Hartley Act was intended to even the balance of bargaining strength by imposing symmetrical obligations. ${ }^{33}$

Like Wagner Act partisans, supporters of the Taft-Hartley Act endorsed the fundamental need to protect collective bargaining. ${ }^{34}$ Therefore, the authors of Taft-Hartley did not amend $\S 7$, the main wellspring of employee rights. However, to curb perceived union abuses of $\S 7$ rights, the authors amended $\S 10(\mathrm{c})$ to limit the scope of protected activity under $\S 7$ by endowing employers with greater protection..$^{35}$

The amended § 10 (c) emphasized that not all "concerted" employee activity should be protected. Supporters of the Taft-Hartley Act disapproved of Board decisions that had expanded the realm of protected activity to include traditionally lawful causes for dismissal or discipline. They specifically argued that the Board had extended protection to employee delinquency, spoiling of goods, and interference with manufacturing. ${ }^{36}$ Supporters of the amendment also argued that the Board had overreached its statutory mandate under the Wagner Act by protecting concerted activity

the isolated wage earner caught in the complex of modern industrialism has become [] a commonplace [and is worsening].").

31 See text accompanying notes 110-11.

32 For example, the Wagner Act prevented an employer from refusing to bargain collectively with employees but did not impose a similar obligation on employees. 29 USC § 158(a)(5) (1988).

ss For example, employees could not refuse to bargain collectively with employers. 29 USC \& 158(b)(3) (1988).

34 See Getman and Blackburn, Labor Relations at 34 (cited in note 3).

35 Many conservative legislators would have preferred to repeal the Wagner Act in full. However, a frontal assault on the Act or on its main provision, § 7, was considered politically impossible. Therefore, these legislators were content to amend $\S 10(\mathrm{c})$ to correct the perceived imbalance in the employee-employer relationship. For a discussion of the discontent with the Wagner Act which led to the amendments (through the Taft-Hartley Act), see id at 31-35 (cited in note 3).

${ }^{36}$ Matter of Wyman-Gordon Company, 62 NLRB 561 (1945). See also HR Rep No 245, 80th Cong, 1st Sess 42 (1947), reprinted in 1 Legislative History of the Labor Management Relations Act 333 (NLRB, 1948) ("The change . . . is intended to put an end to the belief, now widely held and certainly justified by the Board's decisions, that engaging in union activities carries with it a license to loaf, wander about the plants, refuse to work, waste time, break rules, and engage in incivilities and other disorders and misconduct."). 
otherwise unlawful or in breach of a lawful employment contract. The amendments to $\S 10$ (c) were intended to reaffirm the Supreme Court's reversals of such cases where the Board had extended protection. ${ }^{37}$

None of the activities that the amendment addressed included public disparagement of the employer's business activities. ${ }^{38}$ In fact, neither the NLRA nor its legislative history makes reference to public disparagement or "disloyalty." Pressing concerns such as recovering from the Depression and, in the case of the Taft-Hartley Act, concern with quelling post-World War II strikes left little time for debate on the outer limits of $\S 7$ protection. The existing scraps of legislative history suggest a congressional intent, at a minimum, to exempt from protection employee activity whose object violates a statute or NLRA policy or whose means violate a statute or shop rules, as well as an intent to impose equal obligations on employers and unions.

\section{Evolution of the Disloyalty Doctrine}

The disloyalty doctrine originated in the courts. ${ }^{39}$ Though some federal courts came close to articulating the disloyalty doctrine in decisions after the Wagner Act, it did not blossom until Jefferson Standard. ${ }^{40}$ Since Jefferson Standard, the NLRB and federal circuit courts have both extended and contracted the reach of the doctrine, depending on the "disloyalty" test adopted.

${ }^{37}$ See 93 Cong Rec 6600 (Jun 5, 1947) (extension of remarks by Senator Taft), reprinted in 2 Legislative History of the Labor Management Relations Act 1538 (NLRB, 1948). The cases included: Fansteel Metallurgical Corp. v NLRB, 306 US 240, 252 (1939) ("sit-down" strike involving destruction of employer's property not protected); Southern Steamship, 316 US at 39-48 (strike that constituted mutiny under criminal code unprotected); and NLRB v Sands Mfg. Co., 306 US 332 (1939) (strike with objective in violation of collective bargaining agreement not protected). See also HR Rep No 510, 80th Cong, 1st Sess 55 (1947) (Conference Report), reprinted in 1 Legislative History of the LMRA at 559 (cited in note 36) (Communist activities or activities contrary to shop rules also singled out as unprotected).

ss See Local Union No. 1229 v NLRB, 202 F2d 186, 187-88 nn 4-10 (DC Cir 1952) (summarizing opinions prior to the Taft-Hartley Act).

3o See Cynthia L. Eastlund, What Do Workers Want? Employee Interests, Public Interests, and Freedom of Expression Under the National Labor Relations Act, $140 \mathrm{U} \mathrm{Pa} \mathrm{L}$ Rev 921, 989 (1992) (prior to Wagner Act, employment relationship governed by "master and servant" law that included general duty of loyalty forbidding employee from damaging employer's business).

10 346 US at 474-75. 


\section{A. Jefferson Standard}

Jefferson Standard is the touchstone of the disloyalty doctrine. In that opinion, the Court applied the "for cause" language of $\S 10$ (c) to restrict the zone of protected activity under $\S 7.41$ The Court held that concerted activity showing indefensible disloyalty by employees in a labor dispute did not merit the protection of the NLRA. ${ }^{42}$

In Jefferson Standard, a technicians' union had a collective bargaining dispute with a television station, but did not go on strike. During their off hours, some of the technicians distributed handbills severely criticizing the quality of the station's programming, suggesting that their employer treated the city as "second class." 43 The handbills made no reference to the union, collective bargaining, or the ongoing labor dispute.44

The Court of Appeals held that the handbilling was protected, overturning the Board which had held that the handbills were "hardly less 'indefensible' than acts of physical sabotage."45 The Court of Appeals ruled that the Board must find that the handbills were unlawful before it could hold them unprotected.96 The court stated that the line between protected activity and unprotected acts of disloyalty should be drawn at illegality. ${ }^{47}$

4 Id at $472-75$.

${ }^{42}$ Id at 477-78. In addressing sections 7 and 10(c), the Court implied that the analyses of both provisions are the same. Id.

ts The handbill, in full, stated:

Is Charlotte A Second-Class City?

You might think so from the kind of Television programs being presented by the Jefferson Standard Broadcasting Co. over WBTV. Have you seen one of their television programs lately? Did you know that all the programs presented over WBTV are on film and may be from one day to five years old. There are no local programs presented by WBTV. You cannot receive the local baseball games, football games or other local events because WBTV does not have the proper equipment to make these pickups. Cities like New York, Boston, Philadelphia, Washington receive such programs nightly. Why doesn't the Jefferson Standard Broadcasting Company purchase the needed equipment to bring you the same type of programs enjoyed by other leading American cities? Could it be that they consider Charlotte a second-class community and only entitled to the pictures now being presented to them?

WBT TECHNICIANS

Id at 468 .

" Id.

48 Local Union No. 1229, 202 F2d at 188.

${ }^{48}$ Id at 187.88 (section 7 does not protect activities contravening provisions or policies of the NLRA or federal or local statutes compatible with the NLRA). Judge Bazelon's interpretation of $\S 7$ is consistent with both the legislative history and the Supreme Court's holding in Jefferson Standard. See text accompanying notes 22-42.

${ }^{4}$ Local Union No. 1229, 202 F2d at 188. 
On appeal, the Supreme Court ruled that illegality is not the litmus test for protection. The Court held that while employees continue to work they owe a duty not to disparage the product or services of their employer or to hamper her sales, even if such activities would not violate any laws. ${ }^{48}$ It also recognized that this duty persisted during a strike, since strikers intend to return to work and have reinstatement rights. The Court stated that "[t]here is no more elemental cause for discharge of an employee than disloyalty to his employer." $"$ e

Furthermore, the Court was troubled by the technicians' lack of candor. The technicians, in attacking management policies, had not disclosed their true motive: hoped-for concessions at the bargaining table. Though the Court did not decide the case on this basis, it stated that, had the technicians disclosed their motive, their attack would have cost more public support than it would have gained. ${ }^{\text {so }}$

\section{B. Disloyalty Tests}

Since Jefferson Standard, the NLRB and federal circuit courts have extended the scope of the disloyalty doctrine. Labor dispute activities varying dramatically from those in Jefferson Standard have challenged the boundaries of the disloyalty doctrine in such areas as breach of confidentiality, ${ }^{51}$ diversion of business, ${ }^{52}$ and insubordination. ${ }^{53}$ This Comment, however, focuses on public disparagement as a form of disloyalty.

\footnotetext{
18 The Court in Jefferson Standard found the roots of the disloyalty doctrine not only in the Taft-Hartley Act but also in case law before and after that Act. See 346 US at 474-76. See also NLRB v Jones \& Laughlin, 301 US 1, 46 (1937) ("[T]he Board is not entitled to make its authority a pretext for interference with the right of discharge when that right is exercised for other reasons than [] intimidation and coercion"); Hoover Co. $v$ NLRB, 191 F2d 380, 389 (6th Cir 1951) ("'An employee] can not collect wages for his employment, and, at the same time, engage in activities to injure or destroy his employer's business").

40 Jefferson Standard, 346 US at 472. For a critical perspective on the disloyalty doctrine, see Eastlund, $140 \mathrm{U} \mathrm{Pa} \mathrm{L} \mathrm{Rev} \mathrm{at} \mathrm{941-56} \mathrm{(cited} \mathrm{in} \mathrm{note} \mathrm{39)} \mathrm{(the} \mathrm{doctrine} \mathrm{fails} \mathrm{to} \mathrm{ac-}$ count for legitimate employee concerns about product quality).

Bo 346 US at 476-77. At best, nondisclosure of the labor dispute is an alternative ground for decision. Prior to the discussion of nondisclosure, the Court had already stated that the Taft-Hartley Act did not protect attacks on management policies.

${ }^{s 1}$ NLRB $v$ Knuth Brothers, 537 F2d 950, 956 (7th Cir 1976) (disclosing confidential information to customers disloyal); IBM Corp., 265 NLRB 638, 644 (1982) (disclosure of wage data that was legitimately classified as confidential disloyal).

${ }^{62}$ Kenai Air Service, 235 NLRB 931, 934-36 (1978) (employee who planned to use strike to divert business to rival engaged in unprotected disloyalty); Crystal Linen \& Uniform Service, Inc., 274 NLRB 946, 950 (1985) (strikers who worked for employer's competitor and solicited employer's customers to transfer business to competitor engaged in unprotected disloyalty).
} 
The Board and most circuit courts have developed two tests for determining whether public disparagement amounts to unprotected disloyalty. They have examined either the purpose behind the disparagement or the relation of the disparagement to the labor dispute or both. ${ }^{54}$

Unfortunately, these disloyalty tests have produced uneven results. Loose from the moorings of Jefferson Standard, the Board and the circuits have left a patchwork of decisions that provide insufficient predictability in the application of $\S 7$.

1. "Related to" the labor dispute.

Among circuits that have considered the disloyalty doctrine in the public disparagement context, the dominant approach has been to protect only disparagement that is "related to" the labor dispute. .5 To satisfy the "related to" standard, these circuits generally have looked for a connection between the disparagement and the employees' "working conditions." However, circuits have disputed, at least in result if not openly, what constitutes "working conditions" and how close the connection must be.

This dispute has yielded inconsistent results over whether disparagement about, for example, management policies unrelated to the treatment of employees should be protected if the disparagement bears an indirect relation to "working conditions." The Second Circuit in Misericordia Hospital Medical Center $v$ NLRB" held protected nurses' public criticisms of their hospital's patient

\footnotetext{
${ }^{63}$ Reef Industries, Inc., 300 NLRB 134, slip op at 16, (1990) (disparaging T-shirt sent to personnel manager during labor dispute constituted protected activity).

54 The First Circuit may employ another disloyalty test that balances the harm done to the employer against the employee's interest in furthering union policies. In NLRB $v$ Circle Bindery, 536 F2d 447 (1st Cir 1976), a union worker hired at a non-union bindery reported to his union that the shop was taking on jobs from a union printer obligated not to give work to non-union binderies. As a result, the bindery lost the business. The court found that the Board had appropriately examined the extent of harm to the employer by the disparagement against the employee's interest in furthering union policies. See id at 452-53.

${ }^{B 8}$ See, for example, Misericordia Hospital Medical Center v NLRB, 623 F2d 808, 814 (2d Cir 1980).

${ }^{58}$ Id. "Misericordia is only one of a number of decisions that appear to exaggerate, or even manufacture, the element of self-interest that brings section 7 into play." Eastlund, $140 \mathrm{U} \mathrm{Pa} \mathrm{L}$ Rev at 936 (cited in note 39). See also Golden Day Schools, Inc. $v$ NLRB, 644 F2d 834, 840-42 (9th Cir 1981) (day care center workers' complaints to parents about the quality of child care at the center protected); Allied Aviation Service, 248 NLRB 229, 232 (1980), enforcement granted, $636 \mathrm{~F} 2 \mathrm{~d} 1210$ (3d Cir 1980) (mechanic's letter to customers about lax safety practices protected); NLRB v Mount Desert Island Hospital, 695 F2d 634, 640-41 (1st Cir 1982) (nurses' complaints in letter published in newspaper about the quality of medical care protected).
} 
care facilities because of a relation to "working conditions." The hospital in Misericordia had penalized nurses for contributing to a report that focused on problems such as inadequate staffing and emergency room policies and was concerned almost exclusively with the way these problems affected patient care. ${ }^{57}$ Yet the Eighth Circuit in NLRB v Red Top, Inc. ${ }^{88}$ refused protection to similar threats by an employee. The employee of the janitorial service in Red Top threatened to complain to a main customer, a hospital, about the poor job the janitorial service was performing in order to "interfer[e] with the employer's commercial interests" and thereby gain bargaining concessions. ${ }^{69}$ Both cases involved management policies unrelated to the conditions of employment and, therefore, should have reached similar results.

In accord with the Second Circuit, the Board liberally construes what constitutes a relation to "working conditions." For well over a decade, the Board has not denied protection to any employee disparagement of management policies due to an insuffcient relation to "working conditions." Publications, the Board protected employees who sent letters to, among others, the parent corporation alleging shoddy practices in automobile collision research..$^{61}$ The employees predicted harm to the public, not to themselves, through the allegedly decreased safety standards. ${ }^{62}$ As explored in the next section, however, the Board has repeatedly denied $\S 7$ protection based on a purpose test.

\section{The purpose test.}

The Board and most circuits that have considered disparagement under the disloyalty doctrine have also examined the purpose

82 623 F2d at 810-12.

ss 455 F2d 721, 727 (8th Cir 1972). The Third Circuit tacitly agreed. See NLRB v Pincus Brothers, Inc., 620 F2d 367, 375-77 (3d Cir 1980) (employee's distribution of a defamatory leaflet critical of her employer and union with regard to wages was "arguably unprotected" disloyalty).

so 455 F2d at 727.

-0 The "related to" test is satisfied according to the Board as long as a labor dispute exists and the disparagement is a tactic that may resolve that labor dispute. Allied Aviation Service, 248 NLRB 229, 230 (1980) (employees protected where they sent letters to airline customers concerning "sensitive" and "delicate" safety issues concerning airline maintenance procedures).

62280 NLRB 230 (1986). See also Allied Aviation, 248 NLRB 229.

62 280 NLRB at $230-31$. 
of the disparagement to determine disloyalty. ${ }^{63}$ Disparagement that satisfies the "related to" standard may still be denied protection if it serves an improper purpose. To find purpose, the Board and these courts have evaluated the rhetorical tone of the disparagement including such factors as sarcasm, ${ }^{64}$ vulgarity, ${ }^{85}$ immaturity, ${ }^{66}$ and impulsiveness. ${ }^{67}$

Naturally, such a subjective inquiry has yielded uneven results. The Ninth and Second Circuits have held protected harshly worded disparagement that may well have seriously damaged the employer's business. ${ }^{88}$ Meanwhile, the Fourth and Eighth Circuits have refused protection to disparagement milder or comparable in tone. $^{69}$ The Board has rendered similarly asymmetrical holdings. ${ }^{70}$ Without clear, objective standards for judging purpose, such uneven results are unavoidable. ${ }^{71}$

8s For a representative Board opinion, see American Arbitration Ass'n, 233 NLRB 71, 75 (1977) (sarcastic letter written with vengeful purpose to employer's clients concerning dress code disloyal). See also New River, 945 F2d at 1295 (sarcastic letter critical of employer's gift of free ice cream cones "prepared as a lark" disloyal); Golden Day, 644 F2d at 841 (child care workers' leaflet containing harsh language and serious charges about the care of the children protected where designed to protest unlawful discharges); Misericordia, 623 F2d at 814 ("responsible" employee report critical of hospital's operations written to remedy deficiencies in working conditions protected); and Red Top, $455 \mathrm{~F} 2 \mathrm{~d}$ at 727 (threats to complain to customers about management issued to harass employer not protected).

64 See, for example, New River, 945 F2d at 1295 (satirical letter unprotected).

${ }^{65}$ See, for example, Caterpillar Tractor Co., 276 NLRB 1323, 1326 (1985) (vulgarity of cartoon sufficiently offensive to preclude protection).

${ }^{68}$ See, for example, American Arbitration, 233 NLRB at 75 ("childish" and unnecessarily ridiculing disparagement unprotected).

${ }^{67}$ Kroger Co., 284 NLRB 663, 664 (1987) (employees' insulting comments to customers about management protected because employee rights permit "some leeway for impulsive behavior").

${ }^{88}$ See Golden Day, 644 F2d at 841 (publicly distributed leaflet critical of day care center's "cleanliness, teacher's duties, and care of children" protected). See also Misericordia, 623 F2d at 811-14 (employee report critical of deficiencies in emergency room, admissions, and patient care held protected).

${ }^{68}$ See New River, 945 F2d at 1295 (satirical letter concerning employer's gift of ice cream cones to employees unprotected, though containing no vulgarity); Red Top, 455 F2d at 727 (employees' threats unprotected because intended to harass employer and to interfere with customer relations).

${ }^{70}$ Compare American Arbitration, 233 NLRB at 74-75 (sarcastic tone of letters to employer's clients concerning the employer's dress code disloyal), with Emarco, Inc., 284 NLRB 832, 833-35 (1987) (employees protected where they told third-party contractor that employer was no good, did not pay its bills, and could not finish job).

"J Justice Frankfurter presciently hinted at this split in characterizations of labor disputes. Jefferson Standard, 346 US at 481 (Frankfurter, dissenting) ("[T]o float such imprecise notions as 'discipline' and 'loyalty' in the context of labor controversies . . . is to open the door wide to individual judgment by Board members and judges"). See also Sierra Publishing Co. v NLRB, 889 F2d 210, 219 n 13 (9th Cir 1989) ("[M] ost concerted activity could be described in such a way as to place it within either [loyalty or disloyalty]"). 


\section{A New Measure of Disloyalty: The Mandatory and Permissive Subject Distinction}

This Comment proposes that the distinction between mandatory and permissive subjects of bargaining be used as the divide between protected activity and disloyalty in public disparagement cases. Public disparagement of areas subject to mandatory bargaining under $\S 8(\mathrm{~d})$ of the NLRA would be "related to" the labor dispute and, hence, protected; public disparagement of areas subject to permissive bargaining would not be "related to" the labor dispute and, therefore, unprotected. Not only would this imported standard make sense of Jefferson Standard and its progeny in the lower courts, it would also provide greater predictability of results and would lend coherence to two disparate areas of labor law. Moreover, this standard suggests a bilateral obligation of the kind favored by NLRA policy: under the new standard, employers would owe a meaningful duty of loyalty to their employees.

\section{A. Mandatory/Permissive Standard}

Under a standard based on the distinction between mandatory and permissive bargaining subjects, the issue remains whether the disparagement is "related to" the labor dispute. However, since the "related to" standard in its current form is malleable, yielding inconsistent results, the Board and the courts should find that disparagement is "related to" the labor dispute only if it pertains to a subject of mandatory bargaining.

Subjects of mandatory - as opposed to permissive-bargaining involve "wages, hours, and other terms and conditions of employment."72 During negotiations, either the employer or union may press its position on a mandatory subject to impasse and may apply strong economic pressure, such as strikes or lock-outs to achieve bargaining concessions. In contrast to the issue of protected public disparagement, there is exhaustive case law on what is a mandatory subject of bargaining. ${ }^{73}$

7229 USC \& 158(d) (1988). In early cases construing the NLRA, the NLRB held that subjects mentioned in $\S 8$ (d) are mandatory subjects of bargaining. See, for example, Inland Steel Co., 77 NLRB 1, 13 (1948) (pension and retirement plans fall within the statutory duty to bargain collectively).

${ }^{72}$ See Patrick Hardin, ed, 1 The Developing Labor Law: The Board, the Courts, and the National Labor Relations Act 863-928 (BNA Books, 3d ed, 1992) (mandatory bargaining subjects are not limited to the statutory examples; mandatory subjects include provisions for grievance procedures, layoffs, workloads, vacations, sick leave, employee physical 
With permissive subjects, either party may take a position, but neither may insist on its position to impasse. An opponent need not bargain over a permissive subject. Permissive subjects include factors affecting, for example, the relationships between the employer and third parties. ${ }^{74}$

The NLRA's commitment to managerial prerogative, as understood by the Court and the NLRB, drives the distinction between permissive and mandatory subjects of bargaining. The Court has held that a core of entrepreneurial control exists outside the realm of collective bargaining. ${ }^{75}$

\section{B. Managerial Prerogative}

The mandatory/permissive standard is the best proxy for achieving the results the Court in Jefferson Standard intended. Jefferson Standard involved an assault on an area of the business over which the technicians had no rightful control. This assault made "no reference to wages, hours or working conditions." "The Court found, therefore, that the union had gone beyond the bounds of its protected interest. Significantly, the Court's language, quoted above, nearly replicates the $\S 8(\mathrm{~d})$ listing of mandatory bargaining subjects. The Court found that some areas were to be under management's exclusive control.

The Court's regard for managerial prerogative supports a recategorization of the disloyalty doctrine within the established categories of unprotected, concerted activity. As noted in Section II, unprotected, concerted activity has traditionally been divided into

examinations, duration of collective bargaining agreement, bonuses, pensions, insurance plans, company discounts, seniority, and promotions).

${ }^{34}$ See First National Maintenance Corp. $v$ NLRB, 452 US 666, 686 (1981) (termination of contract with customer to provide maintenance workers a permissive subject). See also Otis Elevator Co., 269 NLRB 891, 892-93 (1984), reversing 255 NLRB 235 (1981) (management decision to transfer and consolidate research and development operations rested on a "fundamental change in the nature and direction of the business" and thus was a permissive subject); Fibreboard Paper Products Corp. $v$ NLRB, 379 US 203, 223 (1964) (Stewart concurring) (permissive subjects include choice of advertising and promotion, product type and design, and financing arrangements).

${ }^{76}$ First National Maintenance, 452 US at 676-77; Otis Elevator, 269 NLRB at 893; Fibreboard, 379 US at 223 (Stewart concurring). Justice Stewart coined the phrase "core of entrepreneurial control," and the First National Maintenance decision is based on his concurrence. The legislative history of the NLRA firmly supports the Court's interpretation. See, for example, 79 Cong Rec 7673 (1935), reprinted in 2 Legislative History of the NLRA at 2394 (cited in note 25) (statement of Senator Walsh) (Listing the fundamental rights of an employer, Walsh included the right to close a factory and to set the number of the workforce.).

${ }^{76} 346$ US at 476. 
two categories: activity toward an end that is statutorily unlawful or in violation of an NLRA policy, and activity involving major misconduct or violence. Most commentators place the disloyalty doctrine within the latter category, which includes partial work stoppages and slowdowns. ${ }^{77}$ The mandatory/permissive standard developed in this Comment suggests that the disloyalty doctrine properly falls within the former category because disparagement regarding permissive subjects violates a policy of the NLRA-the safeguarding of managerial prerogative. ${ }^{78}$

Characterizing public disparagement as a violation of NLRA policy when the disparagement aims at permissive subjects of bargaining harmonizes with the policies underlying the NLRA. The legislative history of the NLRA suggests that Congress did not want to protect activity aiming at ends contrary to NLRA policy, or employing means contrary to law or shop rules. ${ }^{78}$ Congress was silent, however, on whether public disparagement aims at forbidden objectives or employs forbidden means. Public disparagement might implicate concerns regarding ends or means. In light of the NLRA's concern for managerial prerogative, the Court in Jefferson Standard necessarily chose to characterize public disparagement as pursuit of an impermissible objective.

\section{The "Related To" Test: A Fresh Look}

The mandatory/permissive standard would resolve much of the confusion among the circuits and the NLRB surrounding the "related to" test. By giving substance to the "related to" language, it would diminish the inconsistency and unpredictability of the "related to" test. ${ }^{80}$ Moreover, this standard would allow most circuits to retain their formal framework for analyzing disloyalty cases.

77 See, for example, Julius G. Getman, The Protection of Economic Pressure by Section 7 of the National Labor Relations Act $115 \mathrm{U} \mathrm{Pa} L \mathrm{Lev}$ 1195, 1231-33 (1967).

78 While this recategorization may at first seem academic, it is significant as the basis for a bilateral obligation of loyalty between employer and employees. See text accompanying notes 101-15.

70 See text accompanying notes $36-39$.

so The body of law and commentary on the distinction between mandatory and permissive subjects is highly developed in comparison to disloyalty. See Note, Decision-Bargaining and the NLRA-A Plea for the Resurrection of First National Maintenance Corporation, 68 Tex L Rev 625, 626 (1990) (Supreme Court distinction on subjects of bargaining clear with high predictability). But see Michael C. Harper, Leveling the Road From Borg-Warner to First National Maintenance: The Scope of Mandatory Bargaining, 68 Va L Rev 1447, 1449 (1982) ("The Supreme Court, far from providing clear and workable restrictions on mandatory bargaining, has aggravated the definitional problem."). 
This standard focuses solely on the subject of the disparagement, rather than on the ultimate bargaining object; thus it is a better proxy for the NLRA's stated policy objectives. In practice, this standard would not protect public disparagement that is only remotely "related to" a labor dispute such as handbills disparaging the nature of a business or public criticism of products. ${ }^{81}$ No longer could employees criticize areas of managerial prerogative as a lever to induce otherwise lawfully sought wage concessions. ${ }^{82}$ Instead, labor would be forced to confront issues directly, thereby fostering a more forthright debate during labor disputes.

Conversely, this standard would protect disparagement that is "related to" any subject over which an employer must negotiate under $\S 8(\mathrm{~d}) .^{83}$ The relation, in effect, is immediate; the context of the $\S 7$ analysis extends no further than the disparagement itself. So long as the subject is a mandatory subject of bargaining, the public disparagement would be lawful. ${ }^{84}$

The mandatory/permissive standard would resolve current circuit splits on public disparagement issues. Cases involving disparagement of management policies that are unrelated to the treatment of employees would be resolved in favor of employers. The management policies criticized in Misericordia and Red Top would have been subjects of permissive bargaining because they fell within the zone of managerial prerogative..$^{85}$

${ }^{31}$ For example, Coca-Cola Bottling Works, Inc., 186 NLRB 1050, 1054 (1970), aff'd NLRB v Coca-Cola Bottling Works, Inc. 466 F2d 380, 394 (DC Cir 1972) (employees distributing leaflets warning of mice and cockroaches in employer's bottles), and Misericordia, 623 F2d at 814 (employee report critical of hospital procedures).

${ }^{82}$ It seems odd that under this proposal employees do not receive the NLRA's protection for exposing, say, public safety hazards but do receive protection for publicly complaining about the size of company lunch halls. For many reasons, though, \& 7 protects the material self-interest of private sector employees, but not the exercise of moral responsibility. The NLRA stands in marked contrast to the public employee speech doctrine under the First Amendment, which protects public employees when speaking on matters of public concern. See Connick v Myers, 461 US 138 (1983).

${ }^{83}$ For example, Community Hospital of Roanoke Valley $v$ NLRB, 538 F2d 607, 609 (televised criticism of salary and benefits).

84 In thus restricting the protection of public disparagement, this standard gives an incentive for more constructive union representation. Congress, in passing the NLRA, decided that employees have their greatest stake in mandatory subjects of bargaining. The proposed restriction to protecting disparagement of mandatory subjects should prevent employees and unions from squandering their bargaining pressure on such permissive subjects as product design.

Bs See Fibreboard, 379 US at 223 (Stewart concurring), and Otis Elevator, 269 NLRB at 892 (decisions based on nature and direction of significant facet of business, rather than on labor costs, are permissive subjects). 
This standard places a stronger emphasis on "labor dispute" in the phrase "related to the labor dispute." The statutory definition of "labor dispute," a jurisdictional requirement under the NLRA, largely mirrors the $\S 8(\mathrm{~d})$ listing of mandatory subjects of bargaining. ${ }^{88}$ Generally stated, employee disparagement of permissive subjects of bargaining is not related to a "labor dispute," though employees and employers remain free to discuss permissive subjects. Thus, an employee cannot have a "labor dispute" over, for example, the employer's product advertising campaign.

Jefferson Standard elevated the importance of the term "labor dispute." The Court in Jefferson Standard severed its analysis of the handbill's disparagement from its analysis of the technicians' drive for better employment terms ${ }^{87}$ Use of the mandatory/ permissive standard would mimic that distinction: disparagement of permissive subjects would fall outside a "labor dispute" and, hence, not merit protection. ${ }^{88}$ Thus, even if the ultimate goal of striking employees were to gain a wage concession-clearly a mandatory subject of bargaining - their disparagement of a permissive subject would not be protected.

\section{Elimination of the Purpose Test}

Importing the mandatory/permissive standard would eliminate the ambiguity of the purpose test. Instead of calling for a subjective evaluation of the rhetorical tone, the new standard would protect all public disparagement that concerns § 8(d) subjects of

s8 29 USC § 152(9) (1988) ("labor dispute" includes "any controversy concerning terms, tenure or conditions of employment, or concerning the association ... of persons in negotiating... [the] terms or conditions of employment ..."). See NLRA of 1935, Comparison of S 2926 (73d Congress) and S 1958 (74th Congress) Senate Committee Print, 74th Cong, 2d Sess 30 (1935), reprinted in 1 Legislative History of the NLRA at 1348 (cited in note 25) ('The term 'labor dispute' is used throughout S 1958 and the committee draft, and is an important jurisdictional requirement in many instances. A carefully phrased as well as a broad definition seems essential.").

${ }^{87}$ See 346 US at 477 ("[T] 7 he findings of the Board effectively separate the attack from the labor controversy and treat it solely as one made by the company's technical experts upon the quality of the company's product. As such, it was as adequate a cause for the discharge of its sponsors as if the labor controversy had not been pending."). See also id at 476 ("The fortuity of the coexistence of a labor dispute affords these technicians no substantial defense.").

st This distinction highlights, within the framework of the NLRA, the difference between public disparagement of a permissive subject and the goal, such as a wage concession, motivating the disparagement. The distinction's significance arises from the policy of safeguarding managerial prerogative. 
mandatory bargaining, regardless of purpose or tone. ${ }^{89}$ Likewise, all public disparagement, however mild, that concerns matters within managerial prerogative would be indefensibly disloyal and, hence, unprotected.90

Eliminating the purpose test is consistent with Jefferson Standard, which gives only dubious support for such a test. Although the Court in Jefferson Standard described the handbills as having a "malicious tone,". the handbills were not defamatory or particularly insulting. ${ }^{91}$ They contained no threats, vulgar language, or sarcasm. Rather, the malice derived from the nature of their attack: the technicians questioned an area of management prerogative. ${ }^{92}$

Little hazard attends the demise of the purpose test. Although employees could become very abusive about their "wages, hours, and other terms and conditions of employment" without fear of reprisal, abuse as economic pressure is not troubling. On the contrary, it serves an end sanctioned by the NLRA. The Court generally permits the use of economic pressure in labor disputes ${ }^{93}$ and the level of abusiveness will likely be limited by the employees' self-interest. Indeed, the Court in Jefferson Standard indicated that verbal "terrorism" was likely to cost employees more public support than it would gain as long as the public realized the source of the criticism. ${ }^{84}$

Moreover, the Court has held protected other speech as harsh as the handbill's rhetoric. In Linn v Plant Guard Workers, Local

\footnotetext{
${ }^{89}$ Naturally, this standard, like other sections of the NLRA, does not prevent the employer's recourse to other avenues of relief, such as defamation actions.

${ }_{80}$ "Unprotected" activity does not automatically receive severe disciplinary action. First, an employer must follow standard procedure-usually written reprimands spelled out in a contract-before the employer may terminate the employee engaged in "unprotected" activity. See NLRB v Transportation Management Corp., 462 US 393, 404 (1983). Second, the doctrine of condonation prevents an employer from terminating such an employee when the employer has tolerated similar behavior in the past. Id. Third, an employer generally may not, by committing unfair labor practices, provoke an employee into indiscreet action and then use the indiscretion as a basis for discharge. See Golden Day, 644 F2d at 842. Fourth, public policy exceptions to the employer's right to discharge may bar reprisals. See Eastlund, $140 \mathrm{U} \mathrm{Pa}$ L Rev at 923 n 8 (cited in note 39) (detailing sources of public policy exceptions as well as whistleblower protection statutes).

21 See text accompanying note 44 .

${ }^{82} 346$ US at 476 ("It was a continuing attack . . . upon the very interests which the attackers were being paid to conserve and develop.").

's See NLRB v Insurance Agents' International Union, 361 US 477, 495 (1960) (“[T] he use of economic pressure ... is not a grudging exception to some policy of completely academic discussion enjoined by the Act; it is part and parcel of the process of collective bargaining").

346 US at 477.
} 
114, the Court acknowledged that the NLRA allows open debate that sometimes includes blunt and reckless language..$^{95}$ With the New York Times Co. v Sullivan libel standard as an outer boundary, the Court approved of the Board's practice of protecting "intemperate, abusive, and inaccurate statements."96 Aside from speech restrictions during union election campaigns, only narrow exceptions to the protection of speech in the labor context exist. ${ }^{97}$

\section{E. Labor Dispute Identification}

The mandatory/permissive standard also largely satisfies the Court's labor dispute identification concern. The Court in Jefferson Standard emphasized that the employees did not identify that the handbills arose out of a labor dispute..$^{98}$ Under the mandatory/ permissive standard, handbills complaining of mandatory subjects such as wages and hours would, as a practical matter, be easily identified as arising out of a labor dispute. ${ }^{99}$

The proposed standard, therefore, removes a counterproductive tactic from labor's bargaining pressure options. This tactic is particularly powerful because the public may not assume that striking employees are making the charges about such matters as product quality. Yet public disparagement of permissive subjects usually hurts both the employer and the employees long after the strike is over. Disparagement of a product may reduce demand,

\footnotetext{
${ }^{95} 383$ US 53, 58 (1966) ("[Labor disputes] are frequently characterized by bitter and extreme charges, countercharges, unfounded rumors, vituperations, personal accusations, misrepresentations and distortions").

96 Id at 61-62. New York Times Co. $v$ Sullivan, 376 US 254, 279-80 (1964), sets a standard for defamation actions brought by public officials that prohibits only the circulation of defamatory material known to be false or with a reckless disregard for the truth. See also Old Dominion Branch No. 496 v Austin, 418 US 264, 282-86 (1974) (exempting derogatory and insulting epithets from state libel law to encourage open labor debate).

${ }^{97}$ Examples include tortious speech and criminal speech. See Farmer $v$ United Brotherhood of Carpenters \& Joiners, 430 US 290, 301-05 (1977) (intentional infliction of emotional distress); Clear Pine Mouldings, 268 NLRB 1044, 1047 (1984) (striking employees threatened to kill non-striking employees).

98346 US at 468, 476-77.

99 The Board would not need to study handbills for, for example, the size and prominence of labor insignia nor for a complete description of the labor dispute. See, for example, Southern California Edison Co., 274 NLRB 1121, 1123-25 (1985) (Board studied buttons worn by employees in detail for significance to public).

Other protected activity under the NLRA, such as primary picketing, is also self-identifying. Pickets that read "Employer X Hires Scabs" need no union signature. Nor does the NLRA require one, even though it otherwise provides a host of regulations on picketing. See 29 USC $\S \S 158(\mathrm{~b})(7), 158(\mathrm{~g})$ (1988). The danger of misleading the public is minimal in both cases: criticism of low wages, for example, triggers an assumption of a labor dispute.
} 
resulting in layoffs. ${ }^{100}$ And, if misleading, the disparagement also hurts consumers without any attendant benefit.

\section{F. A Bilateral Obligation}

Under the duty of loyalty in its current form, neither the Board nor the courts have ever held any employer activity "disloyal" to employees. Indeed, the question of employer disloyalty has never been raised. Instead, unlawful employer activity, such as refusal to bargain collectively, is invariably classified as an unfair labor practice explicitly prohibited by the NLRA. ${ }^{101}$ The duty of loyalty currently binds only employees, yet the NLRA favors bilateral obligations. The impetus behind both the Taft-Hartley and Wagner Acts was the perceived need for similar bargaining strength through bilateral obligations. Supporters of the TaftHartley Act sought symmetry in the statutory obligations on employers and employees. ${ }^{102}$ Likewise, supporters of the Wagner Act believed they were creating symmetry against the backdrop of common law rights enjoyed by the employer. ${ }^{103}$

The mandatory/permissive standard can accommodate a bilateral obligation. Employers would be found disloyal to their employees if they publicly disparaged a permissive subject of bargaining for employees. Permissive subjects of bargaining for employees are few in number and relatively well defined. These areas of employee prerogative include internal union affairs, selection of parties to a collective bargaining agreement, and selection of a bargaining representative. ${ }^{104}$

100 See, for example, Red Top, 455 F2d at 724 (employee threatened to lose main customer of employer). Of course, demand should decline if striking employees publicly complain of low wages, but once the strike is over, the public can usually assume that the strikers are now satisfied and the previous partial boycott should evaporate. In contrast, publicly complaining that a product is shoddily made will have an effect on demand after the strike is over. Reduced demand after the strike is over is almost never in employees' interests.

10129 USC \& 158(a)(5) (1988).

102 For instance, under the Taft-Hartley Act, unions cannot refuse to bargain collectively with their employer. 29 USC $\$ 158(\mathrm{~b})(3)$ (1988). Nor can they restrain or coerce employees exercising their rights under $\$ 7$, which the Taft-Hartley Act amended to include the right to refrain from assisting a labor organization. 29 USC $\S 158(\mathrm{~b})(1)(\mathrm{A})$ (1988). Nor can they cause an employer to discriminate against an employee. 29 USC $\S 158(\mathrm{~b})(2)$. These three obligations on employees correspond to obligations placed on employers by the Wagner Act. See, for example, 29 USC § 158(a)(3) (employers may not discriminate against employees on basis of union membership).

${ }_{103}$ See text accompanying notes 28-31.

104 Hardin, The Developing Labor Law at 424-30 (cited in note 73) (other examples of permissive subjects include a union recognition clause, performance bond, and internal union affairs.) 
For example, the Court has held the relationship between the union and individual employees to be a permissive subject vis-à-vis the employer. ${ }^{105}$ Accordingly, the Board should label an employer's public derision of the union's quality of representation disloyal, and thus an unfair labor practice.

This duty of employer loyalty rests on the policy of safeguarding employee prerogative. The analysis is familiar; it is the converse of safeguarding managerial prerogative. Just as the technicians in Jefferson Standard had no rightful control over programming, management has no rightful control over some areas of employment relations. Again, mandatory and permissive subjects of bargaining properly divide these areas: permissive subjects of bargaining for employees are areas of employee prerogative.

At this point, the recategorization of the disloyalty doctrine becomes instructive. ${ }^{108}$ The traditional view has been that unprotected disloyalty can be classified as major misconduct or violence-that is, such disloyalty violates a statute or a common-law employment duty not overridden by the NLRA. ${ }^{107}$ Within this traditional view, a bilateral obligation of loyalty on employers seems absurd. However, viewing unprotected disloyalty as violative of a policy of the NLRA renders the obligation bilateral. Safeguarding employee prerogative is no less important than safeguarding managerial prerogative.

An employer's invasion of employee prerogative should constitute a $\S 8(a)(1)$ violation. Section $8(a)(1)$ forbids an employer "to interfere with, restrain, or coerce employees in the exercise of the rights guaranteed in section 7." 108 Section 7 creates a zone of employee prerogative regarding, at a minimum, self-organization and the selection of employee representatives. ${ }^{109}$ An employer's public disparagement of union decisions in these areas invades that $\S 7$ zone.

Classifying this kind of conduct as a $\S 8(a)(1)$ violation would be consistent with other $\S 8(\mathrm{a})(1)$ violations. For instance, an employer commits a $\S 8(a)(1)$ violation by interfering with the selection of a bargaining representative. ${ }^{110} \mathrm{~A}$ duty of employer loyalty in this context would render public disparagement of such a selec-

\footnotetext{
${ }^{108}$ See NLRB v Wooster Div. of Borg-Warner Corp., 356 US 342 (1958).

${ }^{100}$ See Section III.B of this Comment.

${ }^{107}$ See text accompanying note 20.

10829 USC \& 158(a)(1) (1988).

109 29 USC $\S 157$ (1988). For the text of $\S 7$ in full, see note 12 .

11029 USC \& 158(a)(1).
} 
tion a type of unlawful interference because selection of a bargaining representative is a permissive subject of bargaining. ${ }^{111}$ Likewise, an employer commits a $\S 8(\mathrm{a})(1)$ violation by interfering with the right to self-organization. The mandatory/permissive standard would protect the exercise of this right from public disparagement since internal union affairs are a permissive subject of bargaining. ${ }^{112}$ In these ways, a duty of employer loyalty merely extends some existing $\S 8(\mathrm{a})(1)$ violations to public disparagement by employers.

Public disparagement of an area of employee prerogative should be an unfair labor practice ("ULP"). ${ }^{113}$ Making such disparagement a ULP allows the employees to file a complaint with the NLRB or, if necessary, to strike over the disparagement itself. ULP strikers are accorded greater protection than "economic" strikers, that is, employees striking over mandatory subjects of bargaining. ULP strikers may not be permanently replaced, ${ }^{114}$ unlike economic strikers. ${ }^{115}$ This remedy would give employees the flexibility to strike over a violation they consider significant or to find a milder form of protest for disparagement they find largely inoffensive.

\section{Conclusion}

The NLRB and the courts have not settled on a satisfactory standard for the disloyalty doctrine. The primary tests for disloyalty have low predictive value, borne out in their inconsistent application. Much of the confusion has stemmed from an incomplete reading of Jefferson Standard and the lack of authoritative legislative history on the outer limits of $\S 7$ protection.

Importing the mandatory/permissive standard into $\S 7$ analysis of disloyalty questions should resolve the confusion. This standard offers more clearly defined borders between protected and unprotected public disparagement than the courts currently offer, and consists of more clearly developed law and scholarship. It also allows courts an escape from inherently murky purpose analyses. Moreover, this standard in practice guards against the possibility of public deception in disparagement cases that the Court recog-

11 See notes 72-75.

112 See id.

113 Just as very few bargaining subject cases involve employee prerogative, few disparagement cases would be likely to involve such a ULP.

114 Mastro Plastics Corp. v NLRB, 350 US 270 (1956).

116 NLRB v Mackay Radio \& Tel. Co., 304 US 333, 345-46 (1938). 
nizes as a danger. Finally, this standard makes sense of Jefferson Standard, because bargaining subject analysis and $\S 7$ analysis under Jefferson Standard share a deep regard for managerial prerogative.

The duty of loyalty under sections 7 and $10(c)$ is not a common law artifact. Rather, the duty springs from the NLRA policy of safeguarding managerial prerogative that the Jefferson Standard Court found in the Taft-Hartley Act. This origin as an NLRA policy supports a meaningful duty of loyalty on employers, so that employers may not through disparagement trample on the equally important policy of safeguarding employee prerogative. Thus, not only can two bodies of labor law be synthesized and streamlined, the opportunity for recognizing a fresh symmetrical duty exists. 
